\title{
A KULTURÁLIS ÖSSZEHASONLÍTÓ PSZICHOLÓGIA 30 ÉVE MAGYARORSZÁGON
}

\author{
FÜLÖP MÁRTA \\ Kognitív Idegtudományi és Pszichológiai Intézet, Természettudományi Kutatóközpont, \\ Budapest, Magyarország \\ Pszichológiai Intézet, Károli Gáspár Református Egyetem, Budapest, Magyarország \\ E-mail: fulop.marta@ttk.hu
}

Benyújtva: 2021. augusztus 23. - Elfogadva: 2021. augusztus 26.

\begin{abstract}
A tanulmány célja a kulturális összehasonlitó pszichológia szakterület elmúlt harminc évének áttekintése, a kutatási területek és az intézményesülés bemutatása. A rendszerváltás elôtti tematikák rövid ismertetése után a rendszerváltás utáni, a rendszerváltás társadalmi-kulturális változásait feltárni kívánó kutatások sorozata következik. A rendszerváltás, a nemzetközi szakmai együttmúködések felszabadításával lehetốvé tette azt, hogy a korábban kutatott tematikák kibốvüljenek és egyre több kutatónak nyíljon arra lehetốsége, hogy egy-egy kutatás erejéig vagy akár kutatássorozatok formájában kulturális összehasonlító vizsgálatokat végezzen. Az utóbbi évtizedben Magyarország ugyancsak képviselteti magát a nagy, sok országra kiterjedô, kulturális összehasonlító kutatásokban is, igy lehetốvé válik számos pszichológiai konstruktum esetében a magyar válaszadókra jellemzö pszichés müködésmódok nemzetközi összehasonlításban történô elhelyezése. A tanulmány bemutatja azokat az intézményi központokat is, amelyek a kulturális összehasonlitó kutatások jelenlegi magyarországi mühelyei, az ott dolgozó kutatókat és a jelenleg kutatott tematikákat.
\end{abstract}

Kulcsszavak: kulturális összehasonlító pszichológia, rendszerváltás, intézményesülés, kutatási területek 


\section{RÖVIDEN A RENDSZERVÁLTÁS ELÔTTI IDŐSZAKRÓL}

A szisztematikus kultúraközi pszichológiai kutatások a hatvanas évek során jelentek meg nemzetközileg a pszichológiai kutatásban. Az elsố tudományos folyóirat, a Journal of Cross-Cultural Psychology 1970-ben indult útjára, vagyis 2020-ban ünnepelte 50. évfordulóját. Ehhez a dátumhoz kötik a pszichológia kulturális forradalmának kezdetét. A Magyar Pszichológiai Szemle kiadása 13 év kényszerszünet után 1960-ban folytatódott. Az elsố tíz éve alatt mindössze két olyan témájú írás (az egyik egy pszichiáter, a másik egy pedagógus tollából) jelent meg benne, amely a kulturális-pszichológiai szempontok fontosságára hívta fel a figyelmet. Az Amerikai Egyesült Államokban a hetvenes évek végére már összegyúlt elegendố kutatási anyag ahhoz, hogy a hatkötetes Handbook of Cross Cultural Psychology 1980-ban megjelenjen (Triandis és Berry, 1980). Ezzel szemben Magyarországon ebben az évtizedben is mindössze két olyan vizsgálat született, amely a kulturális szempontot helyezte a fókuszba (lásd Fülöp Márta összefoglalóját, amelynek a jelen írás egy rövidített változata, kiegészítve a 2013 óta eltelt idôszak kutatási eredményeivel, Fülöp 2009c, 2013).

Az ország zárt volt, magyar kutatók nem mentek külföldre, hogy ott végezzenek összehasonlító kutatásokat, külföldi kutatók hasonlóképpen nem jöhettek Magyarországra adatot gyújteni, és a külföldi kutatókkal való kapcsolattartás és közös munka sem volt a múlt század hatvanas vagy hetvenes éveiben politikailag elfogadott. Az IBM-dolgozókkal zajló nagy nemzetközi vizsgálatban, amely a legfő̉bb kulturális összehasonlítási dimenziók megállapításához vezetett, Jugoszlávia kivételével a többi szocialista ország, így Magyarország sem vett részt (Hofstede, 1980). Halász Lászlónak a francia-magyar elôítéletekre vonatkozó elsố tényleges közös kutatása eredményei - amelyek rámutattak arra, hogy a szocialista Magyarországon felnövekvố iskolások előítéletesebbek, mint az „imperialista” Franciaországban nevelkedô kortársaik - az 1970-es évek elején csak belsố kiadványként jelentek meg (Halász, 1974).

A politikai légkör fokozatos nyitottabbá válásával az 1980-as években gyors fejlódésnek indultak a kulturális összehasonlító vizsgálatok. Ez részben köszönhetố volt az 1970-es évek végén az MTA és az American Council of Learned Societies közötti kutatási megállapodásnak, amelyben kitüntetố szerepet kapott a pszichológia. A megegyezés két kutatási területre szólt, az egyik az irodalompszichológia (Halász László, László János), a másik a döntéspszichológia/kockázatészlelés (Engländer Tibor, Faragó Klára). A részt vevố kutatók mindegyike az MTA Pszichológiai Kutatóintézetének munkatársa volt abban az időben. A nyolcvanas években már arra is lehetôség nyílt, hogy egy-egy kutató személyes kapcsolatok révén alakítson ki kutatási programokat. E tekintetben az ugyancsak az MTA Pszichológiai Intézetében dolgozó Kozéki Béla munkássága egészen kivételes volt. A fơként angol/skót (pl. Kozéki és Entwistle, 1984) összehasonlító vizsgálatsorozatának célja elsôsorban az volt, hogy az általa azonosított tanulási motivációs struktúra univerzalitását bizonyítsa, de a kutatások arra is lehetôséget nyújtottak, hogy a magyar diákok tanulásimotiváció-jellegzetességeirôl tudjon meg többet (lásd Fülöp, 2009b, 2009c, 2013). 
A KULTURÁLIS ÖSSZEHASONLÍTÓ PSZICHOLÓGIA RENDSZERVÁLTÁS UTÁNI FÖBB INTÉZMÉNYES MÉRFÖLDKÖVEI

A magyar kulturális összehasonlító kutatások terén a rendszerváltás hozott létre robbanásszerú változást. Mind a kutatások témaköre, mind a kulturális összehasonlító vizsgálatokat végzók száma, mind a vizsgálatokban részt vevô országok száma tekintetében ugrásszerú növekedés történt. Ebben nyilvánvalóan szerepet játszott az, hogy bármely téma kutathatóvá vált, hogy a magyar kutatók szabadon utazhattak külföldre, és szabadon múködhettek együtt külföldi kollégákkal (Fülöp, 2009c, 2013).

Az elsô lépés a nemzetközi vérkeringésbe történô bekapcsolódásban a rendszerváltás után közvetlenül, a Faragó Klára és Kovács Zoltán által 1991-ben Debrecenben rendezett International Association for Cross-Cultural Psychology (IACCP) konferencia volt. Az MTA Pszichológiai Kutatóintézetében 1998-ban a Japánból hazatérô Fülöp Márta vezetésével megalakult a Kulturális Összehasonlító Pszichológiai Csoport, amelynek Berkics Mihály, Sándor Mónika, Sebestyén Nóra, Orosz Gábor (Fülöp Márta doktori vezetésével) voltak olyan tagjai, akik kulturális összehasonlító vizsgálatokat is végeztek. A csoport jelenleg Társadalom és Kulturális Pszichológia néven múködik a volt MTA Természettudományi Kutatóközpont Kognitív Idegtudományi és Pszichológiai Intézetében.

A 2003-as év több nevezetes eseményt hozott. Ebben az évben alakult meg az Eötvös Loránd Tudományegyetem Pedagógiai és Pszichológiai Kar, amelyen belül 2005-ben létrejött az Interkulturális Pszichológiai és Pedagógiai Központ (késôbb Intézet), amelynek vezetôje Nguyen Luu Lan Anh lett. A központ korszerú szakmai ismereteket nyújt a kulturális pszichológia és pedagógia terén pszichológusoknak és leendô pedagógusoknak. Ugyancsak 2003-ban szerkesztette Nguyen Luu Lan Anh és Fülöp Márta a Kultúra és Pszichológia (Nguyen Luu és Fülöp, 2003) címú tanulmánykötetet, amely az elsố olyan magyar nyelven napvilágot látott mú volt, amely a pszichológiai kutatásokon belül egyre nagyobb teret és szerepet kapó kulturális összehasonlító pszichológia témakörét a legnevesebb nemzetközi szerzók egy-egy kiemelkedô munkájával mutatta be. Szintén 2003-ban rendezte meg Budapesten az International Association for Cross-Cultural Psychology Fülöp Márta és Berkics Mihály szervezésében a második magyarországi nemzetközi konferenciáját, amelyen többek között olyan neves plenáris előadók jelentek meg, mint az Amerikai Pszichológiai Társaság jelenlegi elnöke, a japán származású világhírú kulturális pszichológus, Shinobu Kitayama. A magyar kultúraközi és kulturális pszichológiai vizsgálatokról 2009-ben született meg az elsó összefoglaló áttekintés a Magyar Pszichológiai Szemle különszámaként és a Pszichológiai Szemle Könyvtár sorozatában: Lélek a kultúrák között (szerkesztette Fülöp Márta, 2009c). A legutolsó összefoglaló a 2013-ig terjedô idôszakot foglalja magába, és Fülöp Márta MTA-doktori disszertációjának egyik fejezete (Fülöp, 2013). Interkulturális pszichológia mesterképzés a Károli Gáspár Református Egyetem Pszichológiai Intézetében is - megszakításokkal - több mint tíz éve zajlik.

A magyar kulturális pszichológia 2000 óta képviselteti magát a diszciplína nemzetközi szervezetében az International Association for Cross-Cultural Psychology-ban (IACCP), Fülöp Márta 2004-tôl 2008-ig a vezetôség tagja és az európai régió képviselôje, 2008-tól 2012-ig fôtitkárhelyettes és a Harry and Pola Triandis Doctoral Disser- 
tation Award Bizottság elnöke, 2012-2016 között ismét vezetôségi tag, és az európai régió képviselője, majd 2016-tól 2024-ig a szervezet fớtitkára.

\section{A KULTURÁLIS ÖSSZEHASONLÍTÓ PSZICHOLÓGIA FŐBB VIZSGÁLÓDÁSI TÉMAKÖREI AZ ELMÚLT 30 ÉVBEN}

Az összehasonlító vizsgálatok egy része csak egyszeri „kirándulás” volt egy-egy kutató részérôl, míg mások szisztematikus kutatássorozatokba kezdtek, amelyek alkalmasak voltak valódi kulturális különbségek feltárására és kulturális pszichológiai jelenségek mélyebb megértésére. A kutatások egy része a megkezdett kutatási hagyományokat követte, és lényegében azokat a kutatókat jelentette, akik már a rendszerváltás elôtt is foglalkoztak összehasonlító vizsgálatokkal (pl. irodalompszichológia, kockázatészlelés).

A rendszerváltást követô elsó évtizedben született kutatások egy része magának a rendszerváltásnak a hatásait kívánta követni (pl. a demokrácia szociális reprezentációja nyugat-európai és posztkommunista országokban, a személyes kapcsolatok és a társas támogatottság változásai a társadalmi változások hatására, az akkoriban terjedni kezdô HIV/AIDS percepciója és a kockázatos szexuális magatartás, az igazságos világba vetett hit alakulása más országokhoz képest), vagy a rendszerváltás kulcsjelenségeinek a kutatását túzte ki célul (pl. versengés, gazdasági élet percepciója, a szervezeti kultúra, állampolgáriság), vagy a pszichopatológiai jelenségek alakulását vizsgálta a rendszerváltás tükrében is (pl. öngyilkosság, evészavarok).

A hagyományosan multikulturális társadalmakban, mint Kanada, az USA, Ausztrália vagy Nyugat-Európa számos országa, az utóbbi három évtizedben egyre nagyobb számban jelentek meg az akkulturációra, a kulturális sokkra, az interkulturális kommunikációra vagy a kulturális különbségekre érzékeny pszichoterápiára vonatkozó vizsgálatok, tanulmányok. A rendszerváltás után Magyarország is nyitott lett a bevándorlók számára, és bekapcsolódott a nemzetközi diákcserébe is, és ezzel párhuzamosan megjelentek az olyan kutatások, mint például a Magyarországon tanuló diákok akkulturációja, kulturális adaptációja és magyar diákok külföldi tanulmányainak a hatása.

Egy harmadik csoportba pedig azok a kutatások sorolhatók, amelyek újabb területek és újabb kutatási témák felé nyitottak, mint például a nemi identitásfejlôdést és nemi sztereotípiák alakulását vizsgáló fejlôdéslélektani és a társadalmi nemre vonatkozó kutatások; a pszichológiai jóllétre, optimizmusra vonatkozó vizsgálatok, a szülối magatartás vizsgálatai (anyai versengés), kisgyermekkori megosztás; a pedagógiai szociálpszichológiai vizsgálódások (együttmúködés és versengés iskolai jelenléte), a pszichoterápia alkalmazhatósága különbözô kultúrákban.

\section{A rendszerváltás elôtt megkezdett kutatási hagyományok folytatása}

\section{Irodalompszichológia és kockázatészlelés}

Az amerikai-magyar összehasonlító vizsgálatok az MTA és az ACLS közötti együttmúködésben nem folytatódtak a rendszerváltás után. Halász László ennek ellenére folytatta irodalompszichológiai vizsgálatait svéd, angol, német, olasz összehasonlítás- 
ban (pl. Halász, Asplund Carlsson és Marton, 1991; Halász, Short és Varga, 2002). László János ugyancsak tagja volt az amerikai-magyar irodalompszichológiai közös vizsgálatokat folytató magyar kutatócsoportnak a rendszerváltás elôtt. Közvetlenül a rendszerváltás évében és az azt követô évben végezte dán-magyar összehasonlító vizsgálatát Steen Larsennel (László és Larsen, 1990). Fülöp Márta az irodalmi megértésre vonatkozó nézeteket vizsgálta ugyancsak svéd-magyar összehasonlításban (Asplund Carlsson, Fülöp és Marton, 2001).

Engländer Tibor folytatta korábban megkezdett amerikai-magyar összehasonlító vizsgálatait, amelyekbôl azonban csak egy kiadott publikáció született (Engländer és Czvetkovich, 1993).

\section{A rendszerváltás hatását vizsgáló kutatások}

A versengés kulturális konstrukciója

A rendszerváltás mind politikai, mind gazdasági téren központi fogalommá tette a versengést. Ugyanakkor a versengés fogalma és mintázatai társadalmanként és kultúránként nagyon különbözôek lehetnek. Fülöp Márta kutatásaiban arra kereste a választ, hogy az emberi és társadalmi viszonyrendszerekben elkerülhetetlenül jelen lévô versengés manifesztációi mennyiben kulturális konstrukciók, léteznek-e kulturálisan meghatározott mintázatai. A Japán Alapítvány kutatói ösztöndíjával 1996-1997 között azt kutatta Japánban, hogy milyen versengéskoncepció az, amely lehetôvé teszi a japánok számára, hogy mind intenzíven együttmúködôk, mind intenzíven versengôk legyenek (Fülöp, 2004a, 2006, 2009b). Kutatta, hogy a magyar középiskolások és tanárok tíz évvel a rendszerváltás után milyen szerepet tulajdonítanak a versengésnek a társadalomban japán, amerikai és angol kortársaikhoz és kollégáikhoz képest (Fülöp, 1999a, 1999b, 2001, 2002). A gazdasági oktatás és szocializáció szerepének a versengéshez fúzôdô viszonyra gyakorolt hatását kívánta feltárni Fülöp Márta, Christine Roland-Levy és Berkics Mihály (2004) francia-magyar összehasonlító vizsgálata. Arra voltak kíváncsiak, hogy az eltérô társadalmi-politikai múlttal rendelkezô országokban nevelkedô, gazdasági képzésben részesülő 16-18 éves serdülók versengéssel kapcsolatos szociális reprezentációja miként alakul, és hogyan ítélik meg a versengést általában, a saját személyes életükben és a gazdasági életben. Vizsgálta az üzlet és a versengés reprezentációját üzleti tanulmányokat folytató egyetemisták körében a visegrádi országokban (Fülöp, 2012). A 2010-es évektôl kezdve Fülöp Márta kutatásai kiterjedtek Kínára is, és vizsgálta, hogy milyen gyôzelem-vesztés megküzdési mintázatok jellemzôek a kínai középiskolásokra és egyetemistákra (Fülöp, 2013).

Orosz Gábor (2008, 2009, 2010) magyar és francia közgazdászhallgatók csalási magatartását vizsgálta versengó helyzetben. A kutatás komplex módszertani apparátussal igyekezett feltárni a csalás és a versengés összefüggésének kulturális különbségeit. A versengés és csalás fogalmának reprezentációját a francia szociális reprezentációs iskola hagyományainak megfelelốen asszociációs módszerrel, a csalással kapcsolatos attitúdöket zárt kérdéses kérdôívvel, többek között dilemmákat alkalmazva, a tényleges magatartást pedig kísérleti elrendezésben vizsgálta. 
Erôs Ferenc és kollégái arra voltak kíváncsiak, hogy a rendszerváltás milyen hasonlóságokat és milyen különbségeket eredményezett a posztszocialista országokban. Az öszszehasonlítások rámutattak arra, hogy a rendszerváltás hatásai eltérôek attól függôen, hogy maga a szocialista rendszer milyen jellegzetességekkel bírt az adott országban (pl. Erôs, Murányi, Plichtová és Varga, 1997; Plichtova és Erôs, 1997).

\section{Bizalom és szociális támogatottság}

Robin Goodwin vezetésével, Kósa Éva, Nguyen Luu Lan Anh, George Nizharadze és Tatjana Emelyanova közremúködésével 1995-1996-ban zajlott a társadalmi változások személyes kapcsolatokra és szociális támogatottságra gyakorolt hatásának a vizsgálata. A vizsgálatsorozat három kelet-európai országban (Magyarország és a volt Szovjetunió két köztársasága: Oroszország és Grúzia) zajlott (pl. Nguyen, Kósa, Goodwin, Nizharadze és Emelyanova, 1999; Goodwin, Nizharadze, Nguyen Luu és Emelyanova, 2002).

\section{A HIV-/AIDS-veszély percepciója és a kockázatos szexuális magatartás}

Ugyancsak Robin Goodwin vezetésével Nguyen Luu Lan Anh, Alexandra Kozlova, Anna Kwiatkowska, George Nizharadze és Anu Realo 1995-tôl kezdôdôen egy nagyobb átfogó vizsgálatsorozatot végeztek, amelyból számos publikáció született magyar és angol nyelven (pl. Nguyen, Kovács és Frieze, 2003; Goodwin és mtsai, 2003). A vizsgálat célja az volt, hogy megvizsgálja, miként percipiálják a rendszerváltás után az egyes kelet-európai országokban (így például Oroszországban) gyorsan terjedô HIV-/ AIDS-veszélyt, és milyen szexuális magatartás jellemzô az egészségügyi dolgozókra és üzletemberekre Kelet-Közép-Európa rendszerváltó országaiban.

\section{Az igazságos világba vetett hit és a társas axiómák}

Claudia Dalbert és a korán elhunyt Sallay Hedvig 1996-ban publikálták (Dalbert és Katona-Sallay, 1996) az 1990-ben, közvetlenül a rendszerváltás után kezdôdô vizsgálatsorozatuk eredményeit az igazságos világba vetett hitrôl. A német-magyar kulturális összehasonlító vizsgálatok eredményeit The Justice Motive in Adolescence and Young Adulthood címú, a Routledge könyvkiadónál megjelent könyvükben is összefoglalták (Dalbert és Sallay, 2004). Másfél évtizeddel késôbb Berkics Mihály (2009) magyarlengyel összehasonlító vizsgálata az igazságosságra vonatkozó nézeteket kutatta - hasonlóképpen a korábbi munkákhoz - egyetemisták körében. Berkics Mihály ebben a munkájában elvégezte a mérôeszközök kulturális ekvivalenciájának a vizsgálatát is, amelyet a korábban ismertetett magyarországi kérdốives összehasonlító vizsgálatok egyike sem tett meg.

Fülöp Márta és Berkics Mihály 2000-ben kapcsolódtak be a Kwok Leung és Michael Bond vezette (Bond és mtsai, 2004), 33 országot felölelô társas axióma nemzetközi kutatásba, majd végeztek ebben a témában egy magyar-koreai összehasonlító vizsgálatot is (Fülöp, Berkics, Son és Ko, 2002). 


\section{Gazdasági élet és gazdasági magatartás}

A rendszerváltás a gazdasági élet teljes átrendezôdését kívánta meg a posztszocialista országokban. Gerrit Antonides, Faragó Klára, Rob Raynard és Tadeus Tyska (1997) összehasonlító tanulmányának a célja az volt, hogy feltárja, vajon azonosak-e a gazdasági tevékenységek reprezentációi különbözô társadalmi-gazdasági hagyományokkal rendelkezó országokban. Kovács Judit és Kovács Zoltán (1998) a szocializációnak a gazdasági viselkedésre gyakorolt hatását vizsgálták osztrák-magyar összehasonlításban, egész pontosan azt, hogy milyen hatással van a szocializáció a kétszemélyes cserekapcsolatokban jelen levó együttmúködésre és versengésre, valamint a befolyásolás alakulására.

\section{A szervezetek kultúrája}

A kilencvenes évektôl megjelentek Magyarországon a vegyesvállalatok és a multinacionális cégek. A magyar szervezetpszichológia nem tudta figyelmen kívül hagyni a globalizálódó piaci világ által egyértelmúen felszínre kerülô tényt, mely szerint a szervezeti struktúrák, azok múködtetése, a vezetés és a szervezeti viselkedés jelentôsen különbözhet kultúránként, és a helyi kulturális sajátosságok felismerése és tekintetbevétele jelentôsen meghatározhatja a vállalatok sikerességét. Dénes Eszter (2005) a hatalmi távolság francia és magyar vezetôk vezetôi viselkedésében való megjelenését hasonlította össze. A rendszerváltás után, az 1990-es években lefolytatott legnagyobb méretû, 63 országot magába foglaló és középvezetôket kérdezô, általános és szervezeti kulturális különbségek feltárását célzó GLOBE-vizsgálatban (Global Leadership and Organizational Behavior Effectiveness) magyar pszichológus nem vett részt, a kutatást közgazdász, Bakacsi Gyula vezette (Bakacsi és Takács, 1998; Koopman, Den Hartog, Konrad és Bakacsi, 1999; House, Hanges, Javidan, Dorfman és Gupta, 2004). A GLOBE-vizsgálat legújabb adatfelvétele 2020-ban zajlott, és az eredmények hamarosan várhatók. Lehetôséget adnak majd arra, hogy követni lehessen, milyen kulturális változások zajlottak le az utóbbi 20 évben.

\section{Az állampolgáriság és a vállalkozó mint állampolgár fogalmának kulturális különbségei}

A rendszerváltás egy olyan nyilvánvalóan politikai implikációjú fogalmat is, mint az állampolgáriság, vizsgálhatóvá tett a pszichológia számára. Fülöp Márta és kezdetben Váriné Szilágyi Ibolya, majd késôbb Berkics Mihály magyar részrôl, Alistair Ross, Ian Davies és Merryn Hutchings angol részrôl vettek részt abban a vizsgálatban, amely magyar és angol általános és középiskolai tanárok nézeteit kívánta feltárni az állampolgáriság és a vállalkozás kapcsolatáról, a jó állampolgár és a jó vállalkozó összeegyeztethetôségérôl egy versengố társadalomban (pl. Davies, Fülöp, Hutchings, Ross és Szilágyi-Váry, 2001; Fülöp, Davies, Berkics, Hutchings és Ross, 2004). Az állampolgáriság és a vállalkozás fogalmának szubjektív jelentését egy angol, szlovén, magyar összehasonlító kutatásban tárták fel (Ross és mtsai, 2005), amely a három tudományos akadémia, a brit, a szlovén és a magyar támogatásában valósult meg. A késóbbiekben a vizsgálatokat angol, spanyol, török tanárjelölt egyetemistákra terjesztették ki (pl. Fü- 
löp, Aktan, Davies és Navarro, 2012). A legújabb, fiatalok állampolgári aktivizmusával kapcsolatos, az angol Leverhulme Trust által támogatott, 6 országot felölelô kutatásban magyar részrôl Fülöp Márta vett részt (Peterson, Evans, Fülöp, Kiwan, Sim és Davies, 2020).

\section{Bevándorlás és akkulturáció}

A rendszerváltás után - sok más európai országhoz hasonlóan - Magyarország is bevándorlási célpont lett. Igaz, a bevándorlók száma Európa számos más országához képest igen alacsonynak mondható, mégis azonosíthatók a nagyobb bevándorlócsoportok: a környezô országokból érkezô magyar ajkúakon kívül megjelentek elsôsorban a kínaiak és a vietnámiak. A kínai bevándorlók helyzetét és társas támogatottságát tárta fel az a négy európai országra kiterjedô kutatási program, amelyet Robin Goodwin angol kutató vezetett, és a Brit Akadémia támogatott. A kutatás négy országban zajlott: Angliában, Spanyolországban, Németországban és Magyarországon. A magyar rész vizsgálatvezetôi Nguyen Luu Lan Anh és Fülöp Márta voltak (Fülöp és mtsai, 2007a; Nguyen Luu és mtsai, 2009). Nguyen Luu Lan Anh (2012) Magyarországon élô vietnámi fiatalok és családjaik identitás- és akkulturációs stratégiáiról folytatott kutatást. Az MTA Kognitív Idegtudományi Intézetében Sebestyén Nóra (Sebestyén, 2009, 2013, 2015), az ELTE Interkulturális Pedagógia és Pszichológiai Intézet keretében Borsfay Krisztina (Borsfay és Nguyen Luu, 2018, 2019) folytatott kutatást a kínai bevándorló gyerekek akkulturációjával kapcsolatban.

Az ideiglenes külföldi tartózkodás pszichológiája és a kulturális sokk

A bevándorlás mellett a migráció egy másik formája az ideiglenes külföldön tartózkodás. A globalizáció hatására megélénkült a tanulási célú mobilizáció, növekszik azoknak a diákoknak a száma, akik külföldön kezdik el vagy folytatják tanulmányaikat. Fülöp Márta és Sebestyén Nóra (pl. Fülöp és Sebestyén, 2012) Budapesten tanuló amerikai egyetemisták akkulturációs tapasztalatait és pszichológiai alkalmazkodását kutatta. Fülöp Márta (2010) az Exploring Transculturalism címú kötetben Nacume Szószeki - a 20. század elején élt japán író, a modern japán regény megteremtôje - angliai tanulmányútjának lélektani hatásait elemzi.

Nguyen Luu Lan Anh és tanítványai szisztematikusan kutatják a felsôoktatási nemzetközi mobilitás kulturális vonatkozásait (Hosseini-Nezhad, Safdar és Nguyen Luu, 2019, 2021; Szabó, Papp és Nguyen Luu, 2020). Ennek a kérdésnek Nguyen Luu Lan Anh egy egész kötetet szentelt A nemzetközi hallgatói mobilitás pszichológiai aspektusai (2019) címmel.

\section{A pszichopatológiai jelenségek alakulása a rendszerváltás után: öngyilkosság}

Az öndestruktív magatartás komplex folyamatok eredójeként írható le, de mélyen gyökerező nemzeti és kulturális beágyazottságot mutat. Fekete Sándor és Osváth Péter, a pécsi Pszichiátriai Klinika pszichiáterei a kilencvenes években kezdték meg azt a 
nemzetközi összehasonlító vizsgálatsorozatot, amely azt kívánta feltárni, hogy miként járulhat hozzá az öngyilkosság elterjedtségéhez az adott társadalom öngyilkossággal kapcsolatos attitúd- és normarendszere. Majd az öngyilkossággal kapcsolatos attitúdöket vizsgálták a német, japán, amerikai, finn, osztrák és magyar médiában (pl. Fekete, Domino, Takahashi és Schmidtke, 1998; Osváth és mtsai, 1998), amerikai és magyar öngyilkosok búcsúleveleit hasonlították össze, illetve a nemzeti himnuszokat elemezték az öngyilkossági rátával összefüggésben (Vörös, Osváth, Vincze, Pusztay, Fekete és Rihmer, 2012).

\section{Evészavarok - transzkulturális epidemiológiai vizsgálatok}

A transzkulturális epidemiológiai vizsgálatoknak a transzkulturális pszichiátria (Szilágyi, 2009) megjelenése biztosított kibontakozási lehetôséget, melynek célja a mentális betegségek különbözôségeinek és hasonlóságainak tanulmányozása a különbözô kultúrákban. A kelet-közép-európai régióra vonatkozó evészavaradatok elôször Magyarországon jelentek meg, és csak késôbb más régióbeli országokban (például Cseh Köztársaság, Lengyelország stb.). Ezen a területen a SOTE Magatartástudományi Intézete mellett (Túry Ferenc) a Debreceni Egyetem Pszichológiai Intézetében Szabó Pál és Krizbai Tímea folytattak kutatásokat osztrák, román és erdélyi magyar vonatkozásban is (Rathner, Túry és Szabó, 2001; Kovács [Krizbai] és Szabó, 2009).

\section{A rendszerváltás után megjelenő, a rendszerváltás társadalmi jelenségeihez nem kapcsolódó kutatások}

A rendszerváltás után több olyan kutatás zajlott, amely a kutató saját pályafutásában csak egy rövidebb szakaszt jelentett.

\section{Individualizmus - kollektivizmus}

Csukonyi Csilla, Sallay Hedvig és Münnich Ákos (1999) az individualizmus-kollektivizmus mint társas orientáció szerkezetét vizsgálták, és magyar mintán felhívták a figyelmet arra, hogy ezek nem egymást kizáró dichotóm jellemzók, hanem egy egyén egy idôben jellemezhetô magas individualizmussal és kollektivizmussal vagy alacsony individualizmussal és kollektivizmussal is (Csukonyi, 2003).

\section{Egészség-magatartás és egészségpszichológia}

Brassai László és Pikó Bettina, a Szegedi Tudományegyetem Magatartástudományi Intézetének egyetemi tanára 2000 és 2010 között végzett kutatásai az egészséggel kapcsolatos magatartás kulturális összetevôit vizsgálták magyarországi magyar, erdélyi magyar és amerikai egyetemistákat összehasonlító vizsgálataikban (Brassai, Pikó, Keresztes és Unger, 2006, 2007). Pikó Bettina 2003-ban egy összefoglaló könyvet is közzétett Kultúra, társadalom és lélektan címmel, amelyben a társadalomnak és a kultúrának az egyén személyiségére és magatartására gyakorolt hatásait elemezte (Pikó, 2003). 


\section{Pszichológiai immunitás}

Oláh Attila, Nagy Henriett és G. Tóth Kinga (Oláh, Nagy és Tóth, 2010) 17 országra kiterjedô kutatása azt kívánta feltárni, hogy milyen összefüggés állapítható meg egy adott kultúrában a születéskor várható élettartam (amely az adott kultúrában élốk egészségi állapotának releváns indikátora) és az adott országban élốk pszichológiai immunitásának szintje között.

\section{Az optimizmus pszichológiai kulturális vonatkozásai}

A fiatalon elhunyt kolumbiai származású Cronio Pérez (2004) az optimizmust és peszszimizmust vizsgálta kultúraközi összehasonlításban. Abból indult ki, hogy Magyarországot gyakran emlegetik pesszimistaként, míg a dél-amerikai országokat inkább a túlzott optimizmussal jellemzik. A vizsgálat igazolta az elôzzetes elvárásokat, a kolumbiai egyetemisták optimistábbnak, belsố kontrollosabbnak bizonyultak, és magasabb önértékelésrốl adtak bizonyságot, mint magyar társaik.

\section{A nemi identitás fejlödése, nemi szocializáció}

A fejlődéslélektan területén a rendszerváltás elốtt egyáltalán nem születtek nemzetközi összehasonlító vizsgálatok. Gervai Judit angol-magyar vizsgálatsorozatának adatgyújtési munkái már 1988-ban elkezdôdtek, és 1995-ig folytatódtak. A nemi identitásfejlődést és nemi szocializációt vizsgálták óvodás korban (pl. Gervai, Turner és Hinde, 1993, 1995). Turner és Gervai (1995) azt kívánták megállapítani, hogy azok milyen összefüggésben állnak egymással, például elôrejelzi-e a szülố maszkulinitása és femininitása azt, hogy a gyerek mennyire viselkedik tipikusan fiúsan vagy lányosan.

\section{A magyarországi kulturális és kulturális összehasonlító pszichológiai kutatások két mühelye}

Amint azt a bevezetốben írtuk, a kulturális pszichológiai kutatásoknak két nagyobb mühelye alakult ki, az ELTE Interkulturális Pedagógiai és Pszichológiai Intézetében, Nguyen Luu Lan Anh vezetésével és a (volt MTA) Kognitív Idegtudományi és Pszichológiai Intézetben a Társadalom és Kulturális Pszichológiai Csoportban, Fülöp Márta vezetésével.

\section{Interkulturális Pedagógiai és Pszichológiai Intézet}

Az intézetben jelenleg zajló kulturális pszichológiai vizsgálatok elsốsorban a hallgatói mobilitás kulturális vonatkozásaival foglalkoznak. Az intézet kutatási profiljába tartozik a nemi sztereotípiák vizsgálata is. Nguyen Luu Lan Anh (2001) a nemi sztereotípiákat vietnámi és magyar serdülók között vizsgálta. Ez a vizsgálat volt az elsô délkelet-ázsiai-magyar összehasonlító vizsgálat az országban. Egy másik vizsgálatban a nôk és férfiak iránti attitúdöket hasonlította össze Nguyen Luu Lan Anh, Kovács Mónika és 
Irene Frieze (2003). A magyar-amerikai összehasonlító vizsgálat specifikusan az értékek és a nốk és férfiak iránti ambivalens attitûdök összefüggéseinek összehasonlítását célozta meg.

Az intézetben zajló pedagógiai kutatások az oktatás kulturális kérdéseivel foglalkoznak. A tanulási motiváció elsôsorban kelet-ázsiai és délkelet-ázsiai jellegzetességeinek az elsô összefoglalóját magyar nyelven Gordon Gyóri János adta közre Az oktatás világa Kelet- és Délkelet-Ázsiában (Gordon Gyôri, 2006) címú könyvében, majd a tanulási motiváció kelet-ázsiai és euroamerikai kulturális különbségeirôl a Lélek a kultúrák között kötetben ír (Gordon Gyôri, 2009). Gordon Gyôri János vezetésével az intézet kutatói, Nguyen Luu Lan Anh, Boreczky Ágnes, Czachesz Erzsébet, Szabó Mónika a tanárok multikulturális nézeteit tárták fel kérdôíves és osztálytermi megfigyeléses módszerekkel, és eredményeiket a Tanárok interkulturális nézetei és azok hatása az osztálytermi munkára címú könyvben foglalták össze (Gordon Gyôri, 2014). A bevándorló tanulók mellett kutatások zajlanak a kisebbségi (roma) diákok oktatásával kapcsolatban is (Nguyen Luu, Boreczky és Gordon Gyóri, 2021).

\section{Társadalom és Kulturális Pszichológiai Csoport}

Mieloótt a korábban említett, Japánnal kapcsolatos versengéskutatásokba kezdett volna, Fülöp Márta az anyák közötti versengést vizsgálta finn-magyar összehasonlításban (Fülöp, 1997). A Japánban folytatott kutatások a japán kultúra számos vonásával kapcsolatos munkát indítottak el, így a japánok csoporthoz és közösséghez füzôdó viszonyával foglalkozó elméleti munkát (Fülöp, 1998), a holokauszt és a Hirosima és Nagaszaki elleni atombomba-támadás pszichés következményeinek összehasonlítását (Fülöp, 2003), elemzéseket arról, hogy mennyire „utaztatható” az alapvetôen a nyugati emberkoncepcióra épüló és a lelki egészség kritériumait a szeparált, autonóm individuumban meghatározó pszichoanalízis Kelet-Ázsiába, Japánba és Kínába (Fülöp, 1999c, 2004b), illetve arról, hogy a japán irodalmi múvekben megjelenô emberi viszonyok, érzelmek és pszichés megoldások mennyire felelnek meg a nyugati pszichoanalitikus elméletnek, vagy mennyire tükröznek a nyugatitól eltérô, sajátosan japán megoldásokat (Fülöp, 2008).

Ugyan nem volt munkatársa a kutatócsoportnak, de Fülöp Márta Japánnal kapcsolatos kutatásai inspirálták Indries Krisztiánt, aki doktori tanulmányai során Japánban is kutatott ösztöndíjasként, és azt a kérdést vitte tovább, hogy mennyire összeegyeztethetố a nyugati és a japán pszichoanalízis, illetve milyen módon nyert befogadást a nyugati pszichoanalízis Japánban (Indries, 2008). Egy másik tanulmányában (Indries, 2009) a kelet-ázsiai, ezen belül elsôsorban a japán kommunikációs jellegzetességeket veti alá mélyebb elemzésnek. Részben errôl a témáról készült doktori disszertációjából Szummer Csabával közösen íródott a Freud és a felkelő nap országa címú könyv (Indries és Szummer, 2018).

Afrikával kapcsolatban csak nagyon kevés modern kulturális összehasonlító pszichológiai kutatás áll rendelkezésre, ezért egyedülálló annak a kötetnek a megjelenése, amely különbözó területeken összefoglalja a rendelkezésre álló tudást. Fülöp Márta nemcsak az egyik szerkesztôje a Cross-cultural Psychology Research: An Africa-Cent- 
ric Approach címú könyvnek (Tschombe, Nsanmenang, Heller és Fülöp, 2013), hanem az afrikai versengésre és együttmúködésre vonatkozó kutatásokról is írt Büki Noémivel egy fejezetet (Fülöp és Büki, 2013).

A kutatócsoport számos más területen is kutatta a kulturális különbségeket. Sándor Mónika, Fülöp Márta, Berkics Mihály és Xie Xiaofei (2007) kínai és magyar óvodásokat hasonlítottak össze. A vizsgálat kiinduló kérdése az volt, hogy vajon ebben az életkorban van-e különbség a megosztó viselkedésben az alapvetôen kollektivista kultúrában növekvô kínai és az erôsen individualista társadalomban növekvố magyar óvodások között. A versengés gyermek- és ifjúkori kulturális különbségeirôl Fülöp Márta és Sándor Mónika Barry Schneider kanadai kutatóval írtak összefoglaló fejezetet a Cambridge University Pressnél megjelent kötetbe (Schneider és mtsai, 2006).

A pedagógiai pszichológiai kutatások kiterjedtek a tudással kapcsolatos episztemológiai nézetek kulturális különbségeire (Fülöp és Marton, 2003), az iskolai versengés és együttmúködés angol és szlovén kutatókkal folytatott, az MTA, a British Academy és a Szlovén Tudományos Akadémia támogatásával létrejött vizsgálatsorozatára (Fülöp és mtsai, 2007b), amelybôl könyv is született (Ross, Fülöp és Pergar-Kuscer, 2006). Sebestyén Nóra (2009) és Sebestyén Nóra és Gordon Gyôri János (2009) kínai és magyar szakközépiskolások matematika iránti attitûdjét hasonlították össze. Ugyancsak Sebestyén Nóra a tanulási koncepciókat és az erôfeszítés szerepét, valamint a versengés, a gyôzelem és a vesztés szubjektív jelentését hasonlította össze magyar, kínai és Magyarországon élô kínai diákok esetén, többek között rámutatva az akkulturáció folyamatára (Sebestyén, 2013, 2016; Sebestyén és Fülöp, 2015; Sebestyén, Ivaskevics és Fülöp, 2018).

Sok nemzetre kiterjedô kulturális összehasonlító kutatások: Magyarország részvétele

A rendszerváltás után lehetôség nyílt arra, hogy a nagy nemzetközi kulturális összehasonlító vizsgálatokban magyar kutatók is részt vegyenek, illetve magyar adatokat nemzetközi összevetésben lehessen értékelni. Ezek a kutatások fơképp a Társadalom és Kulturális Pszichológiai Kutatócsoport keretében zajlottak Fülöp Márta mint társkutató vezetésével.

Korábban említettük a sok nemzetre kiterjedô társas axiómákra vonatkozó vizsgálatokat (Bond és mtsai, 2004), de adatok vannak az érzelemkifejezési normákról (Matsumoto és mtsai, 2008, 2009), a partnerválasztási értékekról (Goodwin és mtsai, 2012), a biztonságos internethasználattal foglalkozó, tanároknak, szülőknek és fiataloknak szóló preventív akciótervekrôl (O’Moore és mtsai, 2013). Az énkonstrukció kulturális különbségeirôl egész vizsgálatsorozat zajlott középiskolásokkal és egyetemistákkal (Owe és mtsai, 2013; Becker és mtsai, 2012, 2013; Vignoles és mtsai, 2016). Kutatássorozat foglalkozott a mosoly és a boldogság értelmezésével individualista és kollektivista társadalmakban (Krys és mtsai, 2016, 2020).

A kulturális lazasággal és kötöttséggel foglalkozó, Michele Gelfand vezetésével zajló vizsgálat eredményei a Science folyóiratban jelentek meg (Gelfand és mtsai, 2011), késôbb a kutatók ezt a kulturális dimenziót összekapcsolták az előítéletességgel is (Jackson és mtsai, 2019), majd a normaáthágásra adott társas reakciók kulturális kü- 
lönbségeivel (Erikson és mtsai, 2021). A kapcsolati mobilitás kulturális determinánsaira vonatkozó kutatás eredményeit a kutatók nemrégiben a Proceedings of the American National Academy of Sciencesben (PANAS) jelentették meg (Thompson és mtsai, 2018).

Mindezek a sok nemzetre kiterjedô kutatások lehetôséget teremtenek arra, hogy a magyar eredményeket, magyar kulturális sajátosságokat nemzetközi összehasonlításban, szélesebb kulturális perspektívában lehessen értelmezni.

\section{KÖSZÖNETNYILVÁNÍTÁS}

A szerzô a tanulmány megírása során az NKFIH-OTKA -K 135963 projektámogatásban részesült.

\section{IRODALOM}

Antonides, G., Faragó, K., Raynard, B., \& Tyszka, T. (1997). Perceptions of economic activities: A Cross-country comparison. In G. Antonides, W. F. Raaij, \& S. Maital (Eds), Advances of Economic Psychology (pp. 39-61). Chichester: Wiley and Sons.

Asplund Carlsson, M., Fülöp, M., \& Marton, F. (2001). Peeling the onion. Student teachers' conceptions of literary understanding. Scandinavian Journal of Educational Research, 45(1), $5-17$.

Bakacsi, Gy., \& Takács, S. (1998). Honnan-hová? A nemzeti és szervezeti kultúra változásai a kilencvenes évek közepének Magyarországán. Vezetéstudomány, 12, 15-22.

Becker, M., Vignoles, V. L., Owe, E., Brown, R., Smith, P. B., Fülöp, M., et al. (2012). Culture and the Distinctiveness Motive: Constructing Identity in Individualistic and Collectivistic Contexts. Journal of Personality and Social Psychology, 102(4), 833-855.

Becker, M., Vignoles, V. L., Owe, E., Easterbrook, M., Brown, R., Fülöp, M., et al. (2013). Personality and Social Psychology Bulletin, 40, 657-675. DOI: 10.1177/0146167214522836

Berkics, M. (2009). A disztributív igazságosság észlelése és a rendszerigazolás: kultúrközi összehasonlítás két volt szocialista országban. Magyar Pszichológiai Szemle, 64(1), 229-252.

Bond, M. H., Leung, K., Au, A., Tong, K., Reimel de Carrrasquell, S., Fülöp, M., et al. (2004). Culture-level dimensions of social axioms and their correlates across 41 cultures. Journal of Cross Cultural Psychology, 35, 548-570.

Borsfay, K., \& Nguyen Luu, L. A. (2018). Megküzdés a migránslét kihívásaival. Magyarországi kínai gyerekek akkulturációs tapasztalatainak feltérképezése. Alkalmazott Pszichológia, 18(4), 7-33.

Borsfay, K., \& Nguyen, Luu L. A. (2019). Significant negative transitions in Chinese immigrant children's life. Alkalmazott Pszichológia, 19(3), 53-79.

Brassai, L., Pikó, B., Keresztes, N., \& Unger, J. B. (2006b). Kockázati magatartásformák összehasonlító vizsgálata erdélyi, magyarországi és amerikai egyetemisták körében. Erdélyi Pszichológiai Szemle, 7(4), 311-326.

Brassai, L., Pikó, B., Keresztes, N., \& Unger, J. B. (2007). Az egészségmagatartás és problémaviselkedés egyes kulturális szempontjai. Alkalmazott Pszichológia, 9(1), 31-45.

Csukonyi, Cs., Sallay, H., \& Münnich, Á. (1999). Individualizmus és kollektivizmus: csoportkülönbségek egyetemisták körében. Alkalmazott Pszichológia, 4, 19-31.

Csukonyi, Cs. (2003). Aszociális orientáció - individualizmus és kollektivizmus és a kábítószer-használat összefüggései. In Á. Münnich (Ed.), A kábítószer kipróbálásának okairól, az egyetemi hallgatók körében végzett vizsgálatok alapján (pp. 139-155). Budapest: ELTE Eötvös. 
Dalbert, C., \& Katona-Sallay, H. (1996). The „belief in a just world” construct in Hungary. Journal of Cross Cultural Psychology, 27(3), 293-314.

Dalbert, C., \& Sallay, H. (2004). The justice motive in adolescence and young adulthood. London: Routledge.

Davies, I., Fülöp, M., Hutchings, M., Ross, A., \& Szilágyi-Váry, I. (2001). Enterprising citizens? Perceptions of citizenship education and enterprise education in England and Hungary. Educational Review, 53(3), 261-269.

Dénes, E. (2005). Kultúra és vezetés. Francia és magyar felsôvvezetôk vezetési eszközei. Magyar Pszichológiai Szemle, 9(1), 65-90.

Engländer, F., \& Czvetkovich, G. (1993). A társadalom mint vonatkoztatási keret magyar és amerikai diákok kockázatészlelésében, avagy mi marad meg egy ideológiából. Pszichológia, 13, 333-369.

Erikson, K., Strimling, P., Gelfand, M., Wu, J., Abernathy, J., Akotia, C.S., et al. (2021). Perceptions of the appropriate response to norm violation in 57 societies. Nature Communications, 12, 1481. DOI: https://doi.org/10.1038/s41467-021-2160

Erôs, F., Murányi, I., Plichtová, J., \& Varga, R. (1997). A társadalmi átalakulás és a demokrácia szociális reprezentációja öt posztkommunista országban. Politikatudományi Szemle, 4, 5-27.

Fekete, S., Domino, G., Takahashi, Y., \& Schmidtke, A. (1998). Attitudes toward suicide-a cross-cultural study. In J. L. McIntosch (Ed.), Suicide across the lifespan (pp. 102-105). Washington: AAS.

Fülöp, M. (1997). Mothers' competition through their children. A Finnish-Hungarian comparison. In Sugárné Kádár J. (Ed.), Socialization and the child rearing practice. Acta Psychologica Debrecina, 20, 37-47.

Fülöp, M. (1998). A csoport és a közösség szerepe Japánban. Pszichológia, 3, 469-498.

Fülöp, M. (1999a). Students' perception of the role of competition in their respective countries: Hungary, Japan, USA. In A. Ross (Ed.), Young citizens in Europe (pp. 195-219). London: University of North London.

Fülöp, M. (1999b). Japanese students' perception of the role of competition in their country. Journal of Asian and African Studies, 3(1-2), 148-174.

Fülöp, M. (1999c). A pszichoanalízis alkalmazhatósága különböző kultúrákban. In I. Lust (Ed.), Pszichoanalízis és kultúra (pp. 37-51). Budapest: Animula.

Fülöp, M. (2001). Teachers' perception of the role of competition in their respective countries: Hungary, Japan and USA. Children's Social and Economic Understanding, 4(3), 142-159.

Fülöp, M. (2002). Competition in Hungary and Britain perceived by adolescents. Alkalmazott Pszichológia, 3-4, 33-55.

Fülöp, M. (2003). Társadalmi traumák túlélői nyugaton és keleten: Auschwitz és Hiroshima. In F. Erôs, \& K. Bárdos (Eds), Virág Teréz emlékkötet. Budapest: Thalassa.

Fülöp, M. (2004a). Competition as a culturally constructed concept. In C. Baillie, E. Dunn, \& Y. Zheng (Eds), Travelling facts. The social construction, distribution, and accumulation of knowledge (pp. 124-148). Frankfurt/New York, NY: Campus.

Fülöp, M. (2004b). A pszichoanalízis története és alkalmazhatósága a japán és kínai kultúrában. Thalassa, 15(2), 3-25.

Fülöp, M (2006). Versengés a japán iskolában. In J. Gordon Győri, Az oktatás világa Kelet-és Délkelet-Ázsiában: Japán és Szingapúr (pp. 333-364). Budapest: Gondolat.

Fülöp, M. (2008). Szenvedély, versengés, szégyen és bûntudat japán módra Nacume Szószeki „Kokoro” címú múvében. Lélekelemzés, 3(1), 84-109.

Fülöp, M. (2009a). Happy and unhappy competitors. What makes the difference? Psychological Topics, 18(2), 345-367.

Fülöp, M. (2009b). Kultúraközi és kulturális pszichológia Magyarországon. Magyar Pszichológiai Szemle, 64(1), 3-83. 
Fülöp, M. (2009c) (Ed.). A lélek a kultúrák között. A kulturális különbségek pszichológiája. Budapest: Akadémiai.

Fülöp, M. (2010). Culture shock and the birth of the modern Japanese novel: Natsume Soseki. In A. N. Eigeartaigh, \& W. Berg (Eds), Exploring transculturalism (pp. 63-81). Frankfurt: Verlag für Sozialwissenschaften.

Fülöp, M. (2012.) Az üzlet és a versengés reprezentációja a visegrádi országok leendố gazdasági szakemberei között: kölcsönös bizalom vagy kölcsönös elő́téletek? In Fülöp, M., \& Szabó, É. (Eds), A pszichológia mint társadalomtudomány (pp. 129-153). Budapest: ELTE Eötvös.

Fülöp, M. (2013). A versengés, a gyôzelem és vesztés pszichológiája és kulturális különbségei. MTA Doktori Tanács.

Fülöp, M., Aktan, E., Davies, I., \& Navarro, A. (2012). The cooperative competitive European citizen: is this notion present in the representation of citizenship among student teachers in four countries? In S. Striker (Ed.), Adult education. Historical and theoretical aspects (pp. 11-21). Budapest: ELTE Eötvös.

Fülöp, M., Berkics, M., Son, K. A., \& Ko, J. W. (2002). Hungarian and Korean social axioms. In P. Boski, F. J. R. Van de Vijver, \& A. M. Chodynicka (Eds), Proceedings of the Fifteenth International Congress of the International Association for Cross-Cultural Psychology (pp. 485-501). Warszawa: Institute of Psychology of the Polish Academy of Sciences.

Fülöp, M., \& Büki, N. (2013). Competition and cooperation in Sub-Saharan Africa: a cross-cultural approach. In T. Tschombe, B. Nsanmenang, H. Keller, \& M. Fülöp. (Eds), Cross-Cultural Psychology Research: An Africa-Centric Approach (pp. 353-385). Limbe: Design House.

Fülöp, M., Davies, I., Berkics, M., Hutchings, M., \& Ross, A. (2004). Entrepreneurs and/or citizens. A comparison of English and Hungarian teachers' views on enterprise and the good entrepreneur in a competitive world. Applied Psychology in Hungary, 5-6, 23-46.

Fülöp, M., Goodwin, R., Goebel, K., Grad, H., Martin Rojo, L., Nguyen Luu, L. A., \& Berkics, M. (2007a). Integration of Chinese immigrant children in four countries: Germany, Hungary, Spain and the UK. In A. Ross (Ed.), Citizenship education in society (pp. 331-343). London: London Metropolitan University.

Fülöp, M., \& Marton, F. (2003). Does knowledge exist if nobody knows about it? Eastern and Western knowledge ontologies. In F. Salili, \& R. Hoosain (Eds), Teaching, learning and motivation in a multicultural context (pp. 147-173). Greenwich, CT: Information Age Publishing Company.

Fülöp, M., Roland-Levy, C., \& Berkics, M. (2004). Economic competition perceived by French and Hungarian adolescents. In A. Ross, (Ed.), The experience of citizenship (pp. 325-331). London: London Metropolitan University.

Fülöp, M., Ross, A., Pergar-Kuscer, M., \& Razdevsek Pucko, C. (2007b). Competition and cooperation in schools. An English, Hungarian and Slovenian comparison. In F. Salili, \& R. Hoosain (Eds), Research in multicultural education and international perspective, 6. Culture, motivation and learning: a multicultural perspective (pp. 235-284). Greenwich, CT: Information Age Publishing.

Fülöp, M., \& Sebestyén, N. (2012). Being a student abroad. The sojourner experience: USA meets Hungary. In S. Goncalves, \& M. Carpenter (Ed.), Intercultural policies and education (pp. 141-171). Bern: Peter Lang Publisher.

Gelfand, M. J., Raver, J., Nishii, L., Leslie, L., Lun, J., Fülöp, M., et al. (2011). Differences Between Tight and Loose Cultures: A 33-Nation Study. Science, 332(6033), 1100-1104.

Gervai, J., Turner, P. J., \& Hinde, R. A. (1993). Parents' and teachers' perceptions of personality traits of young children: sex differences, cross-cultural comparisons and relations with observed behaviour. British Journal of Developmental Psychology, 11, 343-358.

Gervai, J., Turner, P. J., \& Hinde, R. A. (1995). Gender-related behaviour, attitudes, and personality in parents of young children in England and Hungary. International Journal of Behavioral Development, 18(1), 105-126. 
Goodwin, R., Nizharadze, G., Nguyen Luu, L. A., \& Emelyanova, T. (2002). Social support in changing Europe: An analysis of three post-Communist nations. European Journal of Social Psychology, 31, 37.

Goodwin, R., Kozlova, A., Kwiatkowska, A., Nguyen Luu, L. A., Nizharadze, G., Realo, A., et al. (2003). Social representations of HIV/AIDS in Central Eastern Europe. Social Science and Medicine, 56, 1373-1384.

Goodwin. R., Marshall, T., Fülöp, M., Adonu, J., Spiewak, S. Neto, F., \& Hernandez Plaza, S. (2012) Mate value and self-esteem: Evidence from eight cultural groups. PLoS One Online http://www.plosone.org/article/info\%3Adoi\%2F10.1371\%2Fjournal.pone.0036106 4.411

Gordon Gyôri, J. (2006). Az oktatás világa Kelet-és Délkelet-Ázsiában. Budapest: Gondolat.

Gordon Gyôri, J. (2009). Kulturális különbségek a tanulási motivációban. Magyar Pszichológiai Szemle, 64(1), 203-228.

Gordon Győri, J. (Ed.) (2014). Tanárok interkulturális nézetei és azok hatása az osztálytermi munkára: kutatási eredmények. Budapest: ELTE Eötvös.

Halász, L. (1974). A „Cigányok” címú film hatásának összehasonlító vizsgálata. Budapest: Tömegkommunikációs Kutató Központ.

Halász, L., Asplund Carlsson, M., \& Marton, F. (1991). Differences in recall and understanding of literary texts read several times. Spiel, 10, 235-262.

Halász, L., Short, M., \& Varga, Á. (2002). A cross-cultural study of fictional and non-fictional text understanding. Poetics, 30, 195-219.

Hofstede, G. (1980). Culture's consequences: International differences in work-related values. Beverly Hills, CA: Sage.

Hosseini-Nezhad, S., Safdar, S., \& Nguyen Luu, L. A. (2021). In a Marathon, Iranians Start at 300 Meters Behind the Starting Line: Psychosocial Adaptation Trajectory of Iranian International Students in Hungary. Journal of International Students, kézirat elfogadva.

Hosseini-Nezhad, S., Safdar, S., \& Nguyen Luu, L. A. (2019). Longing for Independence, Yet Depending on Family Support: A Qualitative Analysis of Psychosocial Adaptation of Iranian International Students in Hungary. International Journal of Higher Education, 8(4), 164-174.

House, R. J., Hanges, P. J., Javidan, M., Dorfman, P. W., \& Gupta, V. (Eds) (2004). Culture, leadership, and organizations: The GLOBE study of 62 societies. Thousand Oaks, CA: Sage.

Indries, K. (2008). Pszichoanalízis Japánban: Sintóista, buddhista mítoszok és az álmok mélystruktúrája. Lélekelemzés, 3(1-2), 110-122.

Indries, K. (2009). A kapcsolati harmónia lélektana a kelet-ázsiai kollektivista társadalmakban. Magyar Pszichológiai Szemle, 64(1), 179-202.

Indries, K., \& Szummer, Cs. (2018). Freud és a felkelō nap országa - A pszichoanalízis Japánban. Budapest: L'Harmattan.

Jackson, J. C., Van Egmond, M., Choi, V. K., Ember, C., Halberstadt, J., Fülöp, M. et al. (2019). Ecological and Cultural Factors Underlying the Global Distribution of Prejudice. PLOS-One, 14(9).

Koopman, P. L., Den Hartog, D., Konrad, E., \& Bakacsi, Gy. (1999). National Culture and Leadership Profiles in Europe: Some Results from the Globe Study. European Journal of Work and Organizational Psychology, 4, 503-520.

Kovács, J., \& Kovács, Z. (1998). A nyereség és méltányosság szempontjai rövid és hosszú távú kapcsolatokban - kultúraközi vizsgálat. Pszichológia, 18(2), 191-207.

Kozéki, B., \& Entwistle, N. J. (1984). Identifying dimensions of school motivation in Britain and Hungary. British Journal of Educational Psychology, 54, 303-309.

Kovács (Krizbai), T., \& Szabó, P. (2009). Az evészavarok epidemiológiai vizsgálata erdélyi román, magyar, illetve szász középiskolások körében. Psychiatria Hungarica, 24(2), 124-132.

Krys, K., Vauclair, M., Capaldi, C., Lun, V., Bond, M., Fülöp, M., et al. (2016). Be careful where you smile: Culture shapes judgments of intelligence and honesty of smiling individuals. Journal of Nonverbal Behavior, 40, 101-116. DOI: 10.1007/s10919-015-0226-4 
Krys, K., Park, J., Kocimska-Zych, A., Kosiarczyk, A., Selim, H., Fülöp, M., et al. (2020). Personal Life Satisfaction as a Measure of Societal Happiness is an Individualistic Presumption: Evidence from Fifty Countries. Journal of Happiness Studies, Article 311. DOI: https://doi. org/10.1007/s10902-020-00311-y

László, J., \& Larsen, S. F. (1990). Kulturális ismeretek és személyes élmények szerepe az irodalom megértésében. Pszichológia, 10(4), 485-508.

Matsumoto, D., Yoo, S. H., Alexandre, J., Anguas-Wong, A. M., Ariola, M., Fülöp, M., et al. (2008). Mapping expressive differences around the world: The relationship between emotional display rules and individualism v. collectivism. Journal of Cross-Cultural Psychology, 39, $55-74$.

Matsumoto, D., Yoo, S. H., Fontaine, J., Alexandre, J., Anguas-Wong, A. M., Ariola, M., Fülöp, M., et al. (2009). Hipocrisy or maturity? Culture and context differentiation. European Journal of Personality, 23(3), 251-264.

Nguyen Luu, L. A. (2001). Nemi sztereotípiák változása a kilencvenes években. In G. Hunyady, \& L. A. Nguyen Luu (Eds), Sztereotípiakutatás (pp. 437-447). Budapest: ELTE Eötvös.

Nguyen Luu, L. A. (2012). Etnokulturális folytonosság, identitás és akkulturáció. In M. Fülöp, \& É. Szabó (Eds), A pszichológia, mint társadalomtudomány (pp. 67-82). Budapest: ELTE Eötvös.

Nguyen Luu, L., Fülöp, M., Goodwin, R., Göbel, K., Martin Rojo, L., Grad, H., \& Berkics, M. (2009). Kínai bevándorló családok gyerekeinek integrációja és szociális támogatottsága. $M a$ gyar Pszichológiai Szemle, 64(1), 139-156.

Nguyen Luu, L. A., Kósa, É., Goodwin, R., Nizharadze, G., \& Emelyanova, T. (1999). Bizalom és szociális támogatottság szociális reprezentációja. Alkalmazott Pszichológia, 1(4), 5-17.

Nguyen Luu, L. A., Goodwin, R., Kozlova, A., Kwiatkowska, A., Nizharadze, G., \& Realo, A. (2003). Értékek és HIV kockázatos viselkedés. Pszichológia, 23(2), 127-137.

Nguyen Luu, L. A. (2019). A nemzetközi hallgatói mobilitás pszichológiai aspektusai. Budapest: Eötvös.

Nguyen Luu, L. A., Boreczky, Á., \& Gordon Gyôri, J. (2021). Minority Parents' Coping Efforts to Improve Their Children's Academic Achievement: the Tanodas in Hungary. In E. Makarova (Ed.), Acculturation and School Adjustment of Minority Students: School and Family-Related Factors (pp. 120-134). Abingdon: Routledge.

Nguyen Luu, L. A., \& Fülöp, M. (Eds) (2003). Kultúra és pszichológia. Budapest: Osiris.

Nguyen Luu, L. A., Kovács, M., \& Frieze, I. (2003). Values and ambivalence towards men and women: A study in Hungary and in the United States. Alkalmazott Pszichológia, 2003-2004, $5-21$.

Oláh, A., Nagy, H. G., \& Tóth, K. (2010). Life expectancy and psychological immune competence in different cultures. Empirical Text and Culture Research, 4, 102-108.

O’Moore, M., Cross, D., Valimaki, M., Almeida, A., Berne, S., Fülöp, M., et al. (2013). Guidelines to prevent cyber-bullying: A cross-national review. In P. K. Smith, \& G. Steffgen (Eds), Cyberbullying through the new media: Findings from an international network (pp. 130-160). London: Psychology Press.

Orosz, G. (2008). Magyar és francia egyetemisták versengésrôl alkotott szociális reprezentációja. Pszichológia, 28(2), 165-194.

Orosz, G. (2009). Csalás a felsôoktatásban francia és magyar közgazdász hallgatók összehasonlító vizsgálata. Magyar Pszichológiai Szemle, 64(1), 253-284.

Orosz, G. (2010). Social representation of competition, fraud and academic cheating of French and Hungarian citizens (p. 473). Reims: University of Reims.

Osváth, P., Fekete, S., \& Takahashi, Y. (1998). Az öngyilkossággal kapcsolatos attitúdök a médiában. Magyar-amerikai-japán összehasonlító vizsgálat. Psychiatria Hungarica, 13, 405-414.

Owe, E., Vignoles, V. L., Becker, M., Brown, R., Smith, P. B., Fülöp, M., et al. (2013). Contextualism as an Important Facet of Individualism-Collectivism: Personhood Beliefs across $37 \mathrm{Na}-$ tional Groups. Journal of Cross-Cultural Psychology, 44, 24-45. 
Perez, C. (2004). Optimizmus-pesszimizmus: Kultúrközi összehasonlító vizsgálat magyar és kolumbiai egyetemisták körében. Pszichológia, 24(1), 1-34.

Peterson, A., Evans, M., Fülöp, M., Kiwan, D., Sim, J. B., \& Davies, I. (2020). Youth activism and education across contexts: towards a framework of critical engagements. Compare: A Journal of Comparative and International Education. December 17. DOI: https://doi.org/10.1080/03 057925.2020.1850237

Pikó, B. (2003). Kultúra, Társadalom és Lélektan. Budapest: Akadémiai.

Plichtova, J., \& Erôs, F. (1997). The significance of political and economic change in two generations of Slovaks and Hungarians. Journal of Community \& Applied Social Psychology, 7, 89-101.

Rathner, G., Túry, F., \& Szabó, P. (2001). Evészavarok a rendszerváltás utáni, az ún. keleti blokk országaiban. Orvosi Hetilap, 124(25), 1331-1333.

Sándor, M., Fülöp, M., Berkics, M., \& Xie, X. (2007). A megosztó viselkedés kulturális és helyzeti meghatározói magyar és kínai óvodáskorú gyerekeknél. Pszichológia, 27(4), 281-310.

Ross, A., Fülöp, M., \& Pergar-Kuscer, M. (Eds). (2006). Teachers' and pupils' constructions of competition and cooperation: a three-country study of Slovenia, Hungary and England. Ljubljana: University of Ljubljana Press.

Ross, A., Read, B., Pergar-Kuscer, M., Fülöp, M., Pucko, C., Berkics, M., et al. (2005). Teachers' constructions of citizenship and enterprise: Using Associative Group Analysis with teachers in Hungary, Slovenia and England. The New Educational Review, 7(3-4), 127-155.

Schneider, B. H, Soteras de Toro, M. P., Woodburn, S., Fülöp, M., Cervino, C., Bernstein, S., \& Sándor, M. (2006). Cross-cultural differences in competition amongst children and adolescents. In X. Chen, D. French, \& B. H. Schneider (Eds), Peer relationships in cultural context (pp. 310-338), New York, NY: Cambridge University Press.

Sebestyén, N. (2009). Kínai és magyar szakközépiskolás diákok matematika iránti attitúdje. $M a-$ gyar Pszichológiai Szemle, 64(1), 157-177.

Sebestyén, N. (2013). Tanuláskoncepciók kulturális beágyazottsága: magyar, kínai és amerikai fiatal felnốttek tanulásfogalmának összevetése. Magyar Pedagógia, 113(1), 3-28.

Sebestyén, N., \& Fülöp, M. (2015). A versengés, győzelem és vesztés szubjektív jelentése magyar, kínai és Magyarországon tanuló kínai diákok körében. Magyar Pszichológiai Szemle, 70(1), 143-158.

Sebestyén, N. (2016). A versengés és a tanulás kulturális beágyazottsága és a migráció hatása a konceptualizációra. Doktori disszertáció. Budapest: ELTE Pszichológiai Doktori Iskola.

Sebestyén, N., \& Gordon Gyôri, J. (2009). Kínai és magyar tanulók motivációs jellemzối a matematikatanulás terén. In Halmos, M., \& Pálfavi, J. (Eds), Matematikatanár-képzés, matematikatanár-továbbképzés: A 2007-2008. évi Varga Tamás módszertani napok kiadványa (pp. 252-260). Budapest: Múszaki.

Sebestyén, N., Ivaskevics, K., \& Fülöp, M. (2018). Narratives of effort among Chinese, Hungarian and Chinese immigrant students in Hungary. International Journal of Psychology, 54(1), $8-16$.

Szabó, A., Z. Papp, Zs., \& Nguyen Luu, L. A. (2020). Social contact configurations of international students at school and outside of school: Implications for acculturation orientations and psychological adjustment. International Journal of Intercultural Relations, 77, 69-82.

Szilágyi, Gy. (2009). A kultúra és a pszichiátria kapcsolata: kulturális pszichiátria. Magyar Pszichológiai Szemle, 64(1), 111-137.

Thomson, R., Yuki, M., Talhelm, T. A., Schug, J., Kito, M., Fülöp, M. et al. (2018). Relational mobility predicts social behaviors in 39 countries and is tied to historical farming and threat. Proceedings of the National Academy of Sciences of the United States of America, June 25, 2018. DOI: $10.1073 /$ pnas.1713191115

Triandis, H. C., \& Berry, J. W. (1980). Handbook of Cross-Cultural Psychology. Boston: Allyn and Bacon, Inc. 
Tschombe, T., Nsanmenang, B., Keller, H., \& Fülöp, M. (2013). Cross-cultural Psychology Research: An Africa-Centric Approach. Limbe: Design House.

Turner, P. J., \& Gervai, J. (1995). A multidimensional study of gender typing in preschool children and their parents: personality, attitudes, preferences, behaviour and cultural differences. Developmental Psychology, 31(5), 759-772.

Vignoles, V. L., Owe, E., Becker, M., Smith, P. B., Easterbrook, M. J., Fülöp, M., et al. (2016). Beyond the 'East-West' dichotomy: Global variation in cultural models of selfhood. Journal of Experimental Psychology: General, 145(8), 966-1000.

Vörös, V., Osváth, P., Vincze, O., Pusztay, K., Fekete, S., \& Rihmer, Z. (2012). Nemzeti himnuszok szóhasználata és tartalomelemzése - elôzetes eredmények egy transzkulturális szuicidium vizsgálatból. Psychiatria Hungarica, 27(3), 174-179.

\section{YEARS OF COMPARATIVE CULTURAL PSYCHOLOGY IN HUNGARY}

\section{FÜLÖP, MÁRTA}

The aim of the paper is to review the past thirty years in the field of cultural comparative psychology, to present research areas and institutionalization. After a brief description of the topics before the change of regime, a series of post-change studies exploring the socio-cultural changes of the change of regime follow. The change of regime, with the release of international professional collaborations, has made it possible to expand the topics previously researched and to give more and more researchers the opportunity to carry out cultural comparative studies to the extent of a single research or even in the form of a series of research. In the last decade, Hungary has also been represented in large, multi-country, comparative cultural research, thus making it possible to place the psychological functioning of Hungarian respondents in international comparisons in the case of many psychological constructs.

The study also presents the institutional centers that are the current workshops of cultural comparative research in Hungary, the researchers working there and the topics currently being researched.

Keywords: comparative cultural psychology, regime change, institutionalisation, research areas

A cikk a Creative Commons Attribution 4.0 International License (https://creativecommons. org/licenses/by/4.0/) feltételei szerint publikált Open Access közlemény, melynek szellemében a cikk bármilyen médiumban szabadon felhasználható, megosztható és újraközölhetô, feltéve, hogy az eredeti szerzô és a közlés helye, illetve a CC License linkje és az esetlegesen végrehajtott módosítások feltüntetésre kerülnek. (SID_1) 